\title{
Interpersonal discourse in the context of intercultural communication (on the example of the Khanty and Russian languages)
}

\author{
S. V. Onina \\ Yugra State University, \\ Khanty-Mansiysk, Russian Federation, \\ oninas@yandex.ru \\ M. S. Vykhrystyuk \\ Yugra State University, \\ Khanty-Mansiysk, Russian Federation, \\ margaritavv@mail.ru \\ Yu. V. Islamova \\ Yugra State University, \\ Khanty-Mansiysk, Russian Federation, \\ islyv@yandex.ru \\ M. G. Baksheyeva \\ Yugra State University \\ Khanty-Mansiysk, Russian Federation, \\ baksheeva.marina@yandex.ru
}

\begin{abstract}
Introduction: the article is devoted to the analysis of interpersonal communication of representatives of the Khanty and Russian cultures. The considered problems of interpersonal discourse of the Khanty and Russian peoples are connected with the search for universals of intercultural interaction, which can unite communicants not on the basis of rejecting the national specific, but on the basis of understanding the «other».

Objective: Analyzing interpersonal discourse we can determine the relationship of the expression of the individuality's inner world with other people. Considering the nature of speech activity we characterize the possible options for the development of foreign speakers' interpersonal discourse as carriers of the Khanty language and representatives of the Russian language.

Research materials: The Khanty and Russian interpersonal discourse in the context of intercultural communication, namely stereotypical language situations on the example of Khanty and Russian languages, became the research material. The study of speech communication through the prism of discourse has made its own adjustments to the interpretation of language and speech. Replacing the understanding of language as a system independent of reality, came the idea of language and speech, between which there is no clear boundary.

Results and novelty of the research: The scientific article for the first time presents a study of the methods of intercultural communication of representatives of different ethnic groups. The article proves that the design of linguistic situations produces an adequate understanding of the actions of people and their causes, which largely determines the construction of relationships with another person.

Key words: interpersonal discourse, intercultural communication, Khanty, Russian, foreign language, cultural institutions.

Acknowledgements: The article was prepared with the financial support of the Russian Foundation for Basic Research: Grant No. 18-412-860005 of the Russian Federation «Dynamics and Constant in the Yugra Language Consciousness»».

The authors are grateful to the distinguished reviewer for useful tips aimed at improving of the quality of the work.

For citation: Onina S. V., Vykhrystyuk M. S., Islamova Yu. V., Baksheyeva M. G. Interpersonal discourse in the context of intercultural communication (on the example of the Khanty and Russian languages) // Vestnik ugrovedenia $=$ Bulletin of Ugric Studies. 2019; 9 (3): 451-460.
\end{abstract}




\title{
Межличностный дискурс \\ в контексте межкультурной коммуникации \\ (на примере хантыйского и русского языков)
}

\author{
С. В. Онина \\ Югорский государственный университет, \\ 2. Ханть-Мансийск, Российская Федеращия, \\ oninas@yandex.ru \\ М. С. Выхрыстюк \\ Югорский государственный университет, \\ 2. Ханть-Мансийск, Российская Федерация, \\ margaritavv@mail.ru \\ Ю. В. Исламова \\ Югорский государственный университет, \\ 2. Ханты-Мансийск, Российская Федерациия, \\ islyv@yandex.ru

\section{М. Г. Бакшеева} \\ Югорский государственный университет, \\ 2. Ханты-Мансийск, Российская Федераџия, \\ baksheeva.marina@yandex.ru
}

\section{АННОТАЦИЯ}

Введение. Статья посвящена анализу межличностного общения представителей хантыйской и русской культур. Рассматриваемые проблемы межличностного дискурса хантыйского и русского народов связаны с поиском универсалий межкультурного взаимодействия, которые могут объединить коммуникантов не на основе отказа от национального специфического, а на основе понимания «иного».

Цель исследования: в процессе анализа межличностного дискурса, определить взаимосвязь выражения внутреннего мира личности с другими людьми.

Материал исследования: хантыйский и русский межличностный дискурс в контексте межкультурной коммуникации, а именно стереотипные языковые ситуации на примере хантыйского и русского языков.

Результаты и научная новизна. В научной статье впервые представлено исследование способов межкультурной коммуникации представителей разных этнических групп - русского народа и народа ханты. В статье доказано, что проектирование языковых ситуаций вырабатывает адекватность понимания действий и поступков людей, выявления их причин, что во многом определяет моделирование взаимоотношений людей друг с другом. По этой причине спроектированные стереотипные ситуации позволяют строить предположения о мотивах и последствиях многих поступков людей разного воспитания, разных религиозных убеждений, разных культур, а также предупредить ошибки в речевом поведении инофонов.

Ключевые слова: межличностный дискурс, межкультурная коммуникация, хантыйский язык, русский язык, инофон, культурные институты.

Благодарности: статья подготовлена при финансовой поддержке РФФИ: Грант №18-412-860005 РФ «Динамика и константа в Югорском языковом сознании».

Авторы благодарны уважаемому рецензенту за полезные советы, направленные на повышение качества работы.

Для циитирования: Межличностный дискурс в контексте межкультурной коммуникации (на примере хантыйского и русского языков) / Онина С. В., Выхрыстюк М. С., Исламова Ю. В., Бакшеева М. Г. // Вестник угроведения. 2019. Т. 9. № 3. С. 451-460. 


\section{Introduction}

In modern scientific and educational literature, the term «intercultural communication» is used in almost all cases when a person belonging to one ethnic group enters into personal contact with a person of another group as the result of the movement of one of the contacts. In such an approach, the source of the perception of another culture is only the directly observed behavior and speech of the individual, which can be neither exhaustive nor just sufficient grounds for a more or less adequate understanding of another culture. In Russian, the word «communication» first appeared in connection with international events. It was the first used by Peter I.

Intercultural communication is the interaction of cultures in the process and the result of direct or indirect contacts between different ethnic or national groups.

No matter what stage we look at, we always and everywhere see that the processes of unification of international social forces are inextricably linked with the processes of communication.

The general function of intercultural communication is the correlation of relations between countries and ethnic groups, classes, layers, national groups, religious organizations, etc. in order to maintain the dynamic unity and integrity of the world socio-cultural structure.

Novelty of the research: the scientific article for the first time presents a study of the methods of intercultural communication of representatives of different ethnic groups - the Russian people and the Khanty people. The analysis of lexical and ethnographic aspects of the Khanty concept of friendship showed that friendly communication between the Russian people and the people of Khanty is so different that without knowledge of ethics of speech behavior of the interlocutor mutual understanding can be difficult.

The article proves that the design of linguistic situations produces an adequate understanding of the actions of people and their causes, which largely determines the construction of relationships with another person. Therefore, stereotypes allow us to speculate about the causes and possible consequences of our own and other people's actions, as well as to prevent errors in the speech behavior of foreign speakers.
University of Yugra is ready to perform the function of education through the introduction of a number of courses on the theory and methods of teaching Khanty languages and cultures.

\section{Materials and Methods}

It is obvious that the results of adaptation will depend on both psychological and socio-cultural factors that are closely related to each other. Good psychological adaptation depends on the type of person, the events in his life, as well as on social support. In turn, effective socio-cultural adaptation depends on the knowledge of culture, the degree of involvement in contacts and intergroup attitudes. Both of these aspects of adaptation depend on a person's conviction of the benefits and success of the integration strategy.

Stereotypes play a very important role in the process of intercultural contacts. By means of stereotypes of the person is allocated with these or those features and qualities. In the process of intercultural communication, one partner perceives the other with his actions and through actions. On the adequacy of understanding the actions and their causes depends largely on the construction of relationships with another person. Therefore, stereotypes allow making assumptions about the causes and possible consequences of their own and others' actions.

By the mid-1980s, Western science had developed the idea that intercultural competence could be acquired through knowledge gained in the process of intercultural communication. This knowledge was divided into specific, which were defined as information about a particular culture in traditional aspects, and general, which included the possession of such communication skills as tolerance, empathic listening, and knowledge of general cultural universals. However, regardless of the division, the success of intercultural communication has always been associated with the degree of mastery of both types of knowledge.

The process of globalization, leading to the interdependence of cultures, peoples and civilizations, necessitates the transition from a hierarchical system of relations based on the principles of domination, subordination, to a system of relations based on the principles of democracy, pluralism and tolerance. At the same 
time, globalization creates preconditions that hamper the dialogue of cultures: the growing diversity of the world, the increasing polarization, the growth of religious fundamentalism and militant nationalism, the inability of existing social institutions to protect any ethnic culture in the new conditions. Here there is a need for consensus, which implies the understanding that the satisfaction of one's own interests is possible taking into account the interests of another.

Integration, recognition of the sovereignty and values of each people and its culture are essential for the survival of peoples in the modern world. This means that the interaction of peoples and cultures should be developed on the basis of the principle of tolerance, expressed in the desire to achieve mutual understanding and coherence, without resorting to violence, the suppression of human dignity, and through dialogue and cooperation.

The global social reality is blurring the boundaries of national cultures, and hence their ethnic, national and religious traditions. In this regard, the theorists of globalization raise the question of trends and intentions of the globalization process in relation to specific cultures [17]: will the progressive homogenization of cultures lead to their fusion in the pot of «global culture», or specific cultures will not disappear, but only the context of their existence will change [18].

In domestic and foreign science has developed a number of approaches to the analysis and interpretation of the processes of modernity, referred to as the processes of globalization [16; $17,84-92 ; 19,711-717 ; 20,96-107 ; 21,523-528]$.

\section{Results}

In this presentation, we will consider the Khanty interpersonal discourse in the context of intercultural communication, simultaneously involving materials for the analysis of interpersonal communication of representatives of different cultures, especially the neighboring Russian culture. Let's try to consider the problems associated with the search for universals of intercultural interaction, which can unite communicants not on the basis of the rejection of the national specific, but on the basis of the understanding of the «other».

Note that «assigning» a new language, foreign students discovers a different world and a different code of speech behavior, which can organically be accepted, or surprise or even rejection. For example, the British, according to the study, characterize Russian speakers as «expressive and emotionally alive» and note their inherent ease in expressing feelings, impulsivity and expansiveness in communication [15]. These psychological features of Russian speech behavior are also largely predetermined by the language. For example, emotional-evaluative vocabulary in Russian is more than 40\%, and in English - not more than $15 \%[9,76]$.

On the one hand, this explains the attitude to emotional openness, sincerity, truthfulness and meaningful and semantic significance of statements, which in the process of interpersonal communication is transformed into the attitude to reciprocity, reflects the traditional value ideas of Russian speakers about proper interaction. On the other hand, native speakers have a well-developed ability of intuitive perception and understanding of unclear information, which is especially important in communicating with the communicant with foreign students. Thus, communication is not only an «appropriation» of norms and rules of verbal behavior: through the lens of a native speaker, foreign students perceive the surrounding social reality. This greatly facilitates the «entry» into the social life of society and Russian discursive practice in General.

«The person, - wrote L.S. Vygotsky, becomes for itself what it is in itself, through what it represents for others» [3, 180]. Therefore, the factor of self-reflection in the other is essential for the formation and development of the relationship.

Consider the originality of the Khanty interpersonal discourse, for example the socalled «paradigmatic case of friendship», known to the representatives of various linguocultural communities. According to the national tradition, «friendship» is characterized in linguistics as «mutual affection of two or more people, their close connection; unselfish, persistent affection based on love and respect or mutual benefits, mutual assistance» $[5,496]$; in ethics as «interpersonal relationships based on common interests and mutual affection». At the same time, the closeness of friendship to the relationship of kinship, partnership and love is noted, which 
reflects the «historical process of differentiation and interpenetration of instrumental (practical mutual assistance and revenue) and emotionally expressive (sympathy, mutual understanding) functions of communication». Unlike partnership, friendship is more individual and selective and involves not only a common position and interests, but also mutual sympathy and emotional attachment [11, 85-86]; in philosophy as «one of the best moral feelings of the person», as «the form of communication of people based on attention and mutual help; assumes personal sympathy, attachment and touches the most intimate, intimate parties of human life» [13, 76-77]; in psychology as «the kind of stable, individual-election of interpersonal relationships, characterized by mutual attachment of their members, strengthening the processes of affiliation, mutual expectations and reciprocal feelings of preference» Observed the dependence of the friendship of common purpose, interests, and ideals, and the relative character of the opposition - with all its intimacy, business and official relations [10, 111-112].

But first, let us consider some important aspects necessary for further analysis.

Analyzing the concept of «friendship» in the culture of different peoples, the famous Polish linguist and culturologist A. Wierzbicka refers the understanding of friendship characteristic of the national tradition to the ethnocentric, i.e. not having universality. Moreover, it was convincingly proved that «friends are recognized as a significant socio-psychological category not by all cultures $<\ldots>$ The taxonomic category of human relations just as cultural and language, as a taxonomic category of emotions, or of speech acts, and the concept encoded in the English word "friend", had in them the attractive status, "wrote researcher in the book" Understanding cultures through key words» $[2,307]$.

The multi-variant manifestation of friendly relations in different linguistic and cultural communities was noted by the English philosopher, specialist in social psychology R. Harré. Answering the question what style friendship implies, the researcher wrote: "In some cultures it is an expansive, unrestrained style. In others - an extremely restrained expression of feelings, coldness, and expansiveness here would be considered a sign of insincerity of expression of friendly feelings» $[14,71]$.

Analyzing the reflection of friendly relations in the Russian, Polish and English pictures of the world, A. Wierzbicka also came to the conclusion that the Russian basic grid for the designation of interpersonal interaction has five lexical units (друг, товарищ, приятель/friend, продруга/ girlfriend, знакомый/acquaintance), Polish - three (przyjaciel, kolega, znajomy), and English - one (friend). According to the researcher, this feature of the language picture of the world reflects the increased interest of Russian speakers «to the sphere of relations between people» $[1,106 ; 16$; 19]. друг, подруга, товарищ, приятель, знакомый

The formulated conclusion was confirmed in a social and psycholinguistic study aimed at studying the Russian everyday consciousness. According to the results, the concept of «communication» includes not only the idea of information exchange («conversation»), but also the nature of community («friends») and interpenetration («talk heart to heart», «deeply understand each other»). The given characteristic can be supplemented by a positive attitude to communication as a means of «maintaining spiritual contact» present in the Russian language picture of the world despite the impracticality of this occupation [6].

Sincerity, sincerity, trust and intensity of friendly relations, which almost all specialists in Russian culture write about, can be perceived by foreigners as undesirable and burdensome in the eyes of representatives of Western culture or even shocking, from the point of view of representatives of the East Asian region [2, 653-658; 1, 101-102; $12,203-204 ; 4,12-15 ; 20]$.

And for the Khanty man, the reaction to the typical Russian manifestations of friendliness is also quite understandable. Indirect, unobtrusive expression Khanty thoughts and feelings and a special delicacy $[7,164 ; 8]$, which excludes the introduction of dissonance in communication, does not fit well with the desire of the Russians to say whatever became of all that was and that in the course of conversation came to mind. Not accepted by the Khanty and emotional admiration or approval in his address, the expression in a situation of companionship. This is due to the fact that the Khanty «rules» of thinking and «feeling» condemn direct praise to the interlocutor. 
Of course, this does not mean that the Khanty have no desire for reciprocity, which is one of the most important functionally conditioned features of human existence [7, 233-245]. But, the social code adopted in the Khanty «ethnic field of behavior and activity» prescribes a different form of friendship. The peculiarity of «friendshiplike» [8] relationships is also manifested in the basic grid, which includes the following lexical

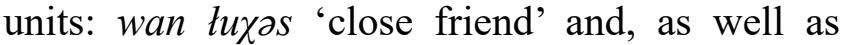
its more official equivalent tuxəs 'friend.' At the same time, Khanty's close friends are called only persons belonging to the same sex pit $\chi u$ 'friend, pitne 'girlfriend'. In addition, there is another word rupittipit (workmate, colleague with the same status) and derivatives jottipit, meaning of players, etc. Thus, the Khanty ethics of friendly communication is aimed at ranking (by sex, significance, importance of work) relationships depending on the status of people.

Naturally, this understanding of friendship is in stark contrast to the Russian, for whom mutual understanding, frankness and openness to each other, trustfulness, active mutual assistance, mutual interest in the affairs and experiences of another, sincerity and selflessness of feelings are typical $[8,111]$. A "Dictionary of Ethics", edited by A. A. Hussein and I.S. Kohn directly indicate the etymological closeness of the concept of "friendship" by the concept of kinship, camaraderie, and love, reflecting the process of differentiation and interpenetration of instrumental (practical mutual aid and revenue) and emotionally expressive (mutual sympathy, emotional attachment, sympathy, understanding) functions of mutual understanding $[9,85]$.

\section{Discussion and Conclusion}

Therefore, friendly communication between Russians and Khanty is so different that without knowledge of ethics of speech behavior of the interlocutor mutual understanding can be difficult. Therefore, it is necessary to get acquainted with the «grammar of culture», that is, with «intuitive laws that form the peculiarities of thinking, feeling, speech and human interaction» [2, 653], is essential in the achievement of reciprocity of the communicants is a foreign language.

Consequently, as can be concluded from the previous brief review, the Khanty language and the interpersonal discourse developing in its space contain at its core value concepts that determine their identity.

The peculiarity of the Russian interpersonal discourse is manifested in the orientation towards achieving in communication the fullness of interaction, mutualunderstanding and relationships. This is reflected in his characteristic attitude of emotional openness, sincerity, truthfulness and significance of statements. As a result, a «common fund» of thoughts, feelings, experiences and value ideas is formed, on the basis of which a common world of communicants is created emotionally, intellectually and spiritually.

It follows from the above that the globalization of the modern world constantly reminds humanity that the world is diverse and at the same time is one, that different approaches to the same processes are inevitable due to different cultures. But at the same time the increasing interdependence of mankind with the need raises the problem of education of the culture of tolerance. World experience shows that the most successful strategy for achieving intercultural competence is integration - the preservation of one's own cultural identity along with the mastery of the culture of other peoples.

According to the German culturologist G. Auernheimer, the training of intercultural competence should begin with directed introspection and critical self-reflection. At an early stage, a willingness to recognize differences between people must be nurtured, which must later develop into the capacity for intercultural understanding and dialogue. To do this, you need to learn to take multicultural compatibility for granted as a condition of life, or rather to teach through the so-called cultural institutions.

Cultural institute in the truest sense more often correlates with various organizations and institutions, directly, directly carrying out the functions of preservation, translation, development, study of culture and cultural phenomena. These include, for example, libraries (preserving its status as a repository of intellectual values), museums, theaters, philharmonic societies, creative unions, societies for the protection of cultural heritage. Educational institutions, such as schools, universities, we can also relate to the concept of cultural institute. Among them are educational institutions directly related to the 
sphere of culture: music and art schools, theater universities, conservatories, institutes of culture and arts. Different cultural institutions can address a common task in an integrated manner, such as the educational function.

Such a function of education in our opinion could provide, for example, the Yugra State University or other universities in the Okrug, in the possible future due to the introduction of the specialty «Theory and methods of teaching Khanty/Mansi languages and cultures». As for the Ob-Ugric and other languages (primarily Russian and foreign languages), an important role can be played by the course "Comparative linguistics», which involves familiarity of students with the basic concepts, terminology, tasks and methods of comparative (contrastive) linguistics, its current state. Some attention is also paid to the history of the study of similarities and differences of languages in translatological, linguodidactic and linguocultural aspects. This discipline may well be part of the block of general professional elective disciplines of the state standard and curriculum, forming a linguist as a specialist.

The pine didactic goal of the course is to prove the importance of comparative linguistics for the general theoretical training of a linguistteacher, linguist, translator and intercultural communication specialist by tracing the links between the theoretical concepts of contrastive linguistics and the practice of intercultural contacts, along with the demonstration of the possibilities of comparative methods of language research. The global coverage of languages is associated with the study of such fundamental to human intellectual and communicative activities of the phenomenon of language universals (universology). Universals are properties common to all or most languages. However, according to linguists (Wilhelm. von Humboldt, N. Chomsky, etc.) the problem of comparison of different language systems is not limited to research interests (comparative and contractibility study of language universals and unions, etc.). Language comparison is a very common everyday reality.

In the situation of language contrast are primarily «naive language users». As the Russian composer M. Glinka said, music is created by people, composers only arrange it. The same is true of language contrasts. Language clashes do not occur on paper on which scientific articles or textbooks are printed. The arena of this collision is the linguistic consciousness of the individual, who studying and comparing languages, faces first of all with those or other «mistakes» in the studied language. They are manifested in the strategies of language behavior of the language user, in the manifestations of what $\mathrm{L}$. Wittgenstein called "silent knowledge», as well as in personal ideas, myths and misconceptions about the essence of language in General, the characteristics of individual languages and their differences. On the one hand, the task of the researcher is to help the naive user to overcome errors, and on the other to find out how the error will help the researcher to understand something in the process of language activity in the field of language contrasts. «Error» naive user decided not to criticize but to examine, in particular, in the interlanguage of deviantology. The teacher, unfortunately, is not a fakir, disciple, fortunately, is not a cobra. Mistakes are a symptom, not a disease, but a mismatch between two language systems and cultures that collide in the learner's mind.

And also a certain educational function can be carried out by the discipline «Theory of intercultural communication», involving the consideration of interpersonal discourse of inophones, which is usually accompanied by familiarity with nationally specific norms and rules of speech behavior, with scenarios of «building relationships» and the range of roles, illuminated by cultural tradition and therefore perceived as natural and expected.

Therefore, the consideration of interpersonal discourse of foreign language would involve, on the one hand, the appeal to the origins of the language and culture of treatment with «their» and «strangers», and with another - the search for universals that could serve as initial support, and their interaction. For a more detailed study, we can offer such a discipline as «Semantic universals and basic concepts». It involves the study of grammatical, word-formation and lexical semantics and analysis of key concepts of different cultures, including Khanty/Mansi and Russian languages and culture (perhaps other, but first of all, start with closely related languages and cultures). 


\section{References}

1. Wierzbicka A. A. Ponimaniye kul 'tur cherez posredstvo klyuchevykh slov [Understanding of cultures through key words]. Moscow: Yazyki slavyanskoy kul'tury Publ., 2001. 288 p. (In Russian)

2. Wierzbicka A. A. Semanticheskiye universalii i opisaniye yazykov [Semantic universals and language description]. Trans. from English by A. D. Shmelev. Moscow: Yazyki slavyanskoy kul'tury Publ., 1999. I-XII. 780 p. (In Russian)

3. Vygotsky L. S. Razvitiye vysshikh psikhicheskikh funktsiy: iz neopublikovannykh trudov [Development of higher mental functions: from unpublished works]. Moscow: Izd-vo APN RSFSR Publ., 1960. 500 p. (In Russian)

4. Grigoryeva E. P. Dialog i kommunikatsiya - filosofskiye problemy (Materialy «Kruglogo stola») [Dialogue and communication - philosophical problems (Materials of the «Round table»)]. Voprosy filosofii [Issues of philosophy], 1998, no 7, pp. 12-15. (In Russian).

5. Dal V. I. Tolkovyy slovar zhivogo velikorusskogo yazyka [Explanatory dictionary of the living Great Russian language]. Moscow: Russkiy yazyk Publ., 1978. 699 p. (In Russian)

6. Zaliznyak A. A. «Slovo o polku Igoreve»: vzglyad lingvista [«The Tale of Igor's Campaign »: view of a linguist]. Moscow: Yazyki slavyanskoj kul'tury Publ., 2004. 355 p. (In Russian)

7. Onina S. V. Imperativ v grammaticheskoj systeme hantyjskogo yazyka [Imperative in the grammatical system of the Khanty language]. Khanty-Mansiysk: Print Class Publ., 2017. 291 p. (In Russian)

8. Onina S. V., Vyhrystyuk M. S. Obraz cheloveka v yugorskom natsional'no-kul'turnom yazykovom soznanii [The image of a man in the Yugra national-cultural linguistic consciousness]. Aktual'nyye problemy gumanitarnykh nauk: Istoriya i sovremennost'. Kollektivnaya monografiya [Actual problems of the Humanities: History and modernity. Collective monograph]. Moscow: [w/p], 2018. pp. 243-264 (In Russian)

9. Petrov M. K. Yazyk. Znak. Kultura [Language. Sign. Culture]. Moscow: Editorial URSS Publ., 2004. 328 p. (In Russian)

10. Psikhologiya. Slovar [Psychology. Dictionary]. Ed. by A. V. Petrovsky, M. G. Yaroshevsky. Moscow: Politizdat Publ., 1990. 494 p. (In Russian)

11. Slovar po etike [Dictionary on ethics]. Ed. by A. A. Guseynov, I. S. Kon. Moscow: Progress Publ., 1989. 447 p. (In Russian)

12. Sternin I. A. Vvedeniye v rechevoye vozdeystviye [Introduction to speech influence]. Voronezh: Izd-vo VGU Publ., 2001. 232 p. (In Russian)

13. Filosofskaya entsiklopediya. V 5 t. [Philosophical Encyclopedia. In 5 vol.]. Moscow: Sovetskaya entsiklopediya Publ., 1962. Vol. 2. 575 p. (In Russian)

14. Harré R. Druzhba kak dostizheniye: etnogeneticheskiy podkhod [Friendship as achievement: ethnogenetic approach]. Mezhlichnostnoye obshcheniye [Interpersonal communication]. Saint-Petersburg: Piter Publ., 2014. pp. 71-77. (In Russian)

15. Shmelev A. D. Russkaya yazykovaya model'mira: Materialy k slovaryu [Russian language model of the world: Materials to the dictionary]. Moscow: Yazyki slavyanskoj kul'tury Publ., 2002. 224 p. (In Russian)

16. Big new English-Russian Dictionary. Available at: https://slovar-vocab.com/english-russian/big-new-vocab. html (accessed January 09, 2019). (In English)

17. Karabulatova I., Akhmetova B., Shagbanova Kh., Loskutova E., Sayfulina F., Zamalieva L., Dyukov I., Vykhrystyuk M. Shaping positive identity in the context of ethnocultural information security and the struggle against the Islamic state. Central Asia the Caucasus, 2016, no. 17 (1), pp. 84-92. (In English)

18. Salo Merja. Passive and Reflexive Categories in Languages of the Volga Region. An Areal Typological Study. Helsinki: University of Helsinki, 2015. 240 p. (In English)

19. Vyhrystyuk M., Onina S. V., Islamova Yu., Savchuk I. P. The Image of the Family in the Modern Advertising Discourse of Russian Media. Astra Salvensis: review of history and culture, 2018, year VI, no. 12, pp. 711-717. (In English)

20. Vykhrystyuk M. S., Akhmetova B., Shagbanova K., Loskutova E., Sayfulina F., Zamalieva L. The influence of the social characteristics of primary school teachers on the development of the younger schoolboy. International Journal of Sciences and Research, 2018, no. 74 (8/1), pp. 96-107. (In English)

21. Vykhrystyuk M. S., Petrova T. A., Tokareva E. Y. Russian language and communication functions in modern world. International multidisciplinary scientific conference on social sciences and arts. Anthropology, archaeology, history \& philosophy. Conference proceedings. August 24-30, 2016, Albena. Bulgaria: [w/p], 2016. Vol. II. pp. 523528. (In English)

\section{Список источников и литературы}

1. Вежбицкая А. А. Понимание культур через посредство ключевых слов М.: Языки славянской культуры. 2001. 288 с. 
2. Вежбицкая А. А. Семантические универсалии и описание языков [Пер. с англ. А. Д. Шмелёва]. М.: Языки русской культуры 1999. I-XII. 780 c.

3. Выготский Л. С. Развитие высших психических функций: из неопубликованных трудов. М.: Изд-во АПН РСФСР, 1960. $500 \mathrm{c}$.

4. Григорьева Т. П. Диалог и коммуникация - философские проблемы (Материалы «Круглого стола») // Вопросы философии. 1898. № 7. С. 12-15.

5. Даль В. И. Толковый словарь живого великорусского языка. М.: Русский язык, 1978. 699 с.

6. Зализняк А. А. «Слово о полку Игореве»: взгляд лингвиста. М.: Языки славянской культуры, 2004. 355 с.

7. Онина С. В. Императив в грамматической системе хантыйского языка. Ханты-Мансийск: Принт-Класс, 2017. $291 \mathrm{c}$.

8. Онина С. В., Выхрыстюк М. С. Образ человека в югорском национально-культурном языковом сознании // Актуальные проблемы гуманитарных наук: История и современность. М.: [б.и.], 2018. С. 243-264.

9. Петров М. К. Язык. Знак. Культура. М.: Едиториал УРСС, 2004. 328 с.

10. Психология. Словарь / Под ред. А. В. Петровского, М. Г. Ярошевского. М.: Политиздат, 1990. 494 с.

11. Словарь по этике / Под ред. А. А. Гусейнова и И. С. Кона. М.: Политиздат, 1989. 447 с.

12. Стернин И. А. Введение в речевое воздействие. Воронеж: Истоки, 2001. 232 с.

13. Философская энциклопедия. В 5 т. М.: Советская энциклопедия, 1962. Т. 2.575 с.

14. Харре Р. Дружба как достижение: этногенетический подход // Межличностное общение. СПб.: Питер, 2001. С. $59-80$.

15. Шмелёв А. Д. Русская языковая модель мира: Материалы к словарю. М.: Языки славянской культуры, 2002. $224 \mathrm{c}$.

16. Big new English-Russian Dictionary. Available at: https://slovar-vocab.com/english-russian/big-new-vocab. html (accessed January 09, 2019).

17. Karabulatova I., Akhmetova B., Shagbanova Kh., Loskutova E., Sayfulina F., Zamalieva L., Dyukov I., Vykhrystyuk M. Shaping positive identity in the context of ethnocultural information security and the struggle against the Islamic state // Central Asia the Caucasus. 2016. No. 17 (1). Pp. 84-92.

18. Salo Merja. Passive and Reflexive Categories in Languages of the Volga Region. An Areal Typological Study. Helsinki: University of Helsinki, 2015. 240 p.

19. Vyhrystyuk M., Onina S. V., Islamova Yu., Savchuk I. P. The Image of the Family in the Modern Advertising Discourse of Russian Media // Astra Salvensis: review of history and culture. 2018. Year VI. No. 12. Pp. 711-717.

20. Vykhrystyuk M. S., Akhmetova B., Shagbanova K., Loskutova E., Sayfulina F., Zamalieva L. The influence of the social characteristics of primary school teachers on the development of the younger schoolboy // International Journal of Sciences and Research. 2018. No. 74 (8/1). Pp. 96-107.

21. Vykhrystyuk M. S., Petrova T. A., Tokareva E. Y. Russian language and communication functions in modern world // International multidisciplinary scientific conference on social sciences and arts. Anthropology, archaeology, history \& philosophy. Conference proceedings. August 24-30, 2016, Albena. Bulgaria: [w/p], 2016. Vol. II. Pp. 523-528.

\section{ABOUT THE AUTHOR:}

Onina Sofya Vladimirovna, Leading Researcher, Yugra State University (628012, Russian Federation, KhantyMansiysk Autonomous Okrug - Yugra, Khanty-Mansiysk, Chekhova st., 16), Candidate of Philological Sciences.

ORCID ID: 0000-0002-3003-993X

oninas@yandex.ru

Vykhrystyuk Margarita Stepanovna, Professor, Department of Philological Education, Tobolsk Pedagogical Institute of D. I. Mendeleeva (branch) of Tyumen State University (626150, Russian Federation, Tyumen Oblast, Tobolsk, Znamenskogo st., 58); Professor of the Russian Language and Literature Department, Yugra State University (628012, Russian Federation, Khanty-Mansiysk Autonomous Okrug - Yugra, Khanty-Mansiysk, Chekhova st., 16), Doctor of Philological Sciences.

margaritavv@mail.ru

ORCID ID: 0000-0001-7955-7351

Islamova Yulia Valeryevna, Associate Professor of the Russian Language and Literature Department, Yugra State University (628012, Russian Federation, Khanty-Mansiysk Autonomous Okrug - Yugra, Khanty-Mansiysk, Chekhova st., 16), Candidate of Philological Sciences.

ORCID ID: ORCID ID: 0000-0003-3752-8418

islyv@yandex.ru 
Baksheeva Marina Gennadievna, Associate Professor of the Russian Language and Literature Department, Yugra State University (628012, Russian Federation, Khanty-Mansiysk Autonomous Okrug - Yugra, KhantyMansiysk, Chekhova st., 16), Candidate of Philological Sciences.

ORCID ID: 0000-0002-3248-165X

baksheeva.marina@yandex.ru

\section{ИНФОРМАЦИЯ ОБ АВТОРАХ:}

Онина Софья Владимировна, доцент кафедры русского языка и литературы, Югорский государственный университет (628012, Российская Федерация, Ханты-Мансийский автономный округ - Югра, г. Ханты-Мансийск, ул. Чехова, д. 16), кандидат филологических наук.

ORCID ID: 0000-0002-3003-993X

oninas@yandex.ru

Выхрыстюк Маргарита Степановна, профессор кафедры филологического образования, Тобольский педагогический институт им. Д. И. Менделеева (филиал) Тюменского государственного университета (626150, Российская Федерация, г. Тюмень, ул. Знаменского, д. 58); профессор кафедры русского языка и литературы, Югорский государственный университет (628012, Российская Федерация, Ханты-Мансийский автономный округ - Югра, г. Ханты-Мансийск, ул. Чехова, д. 16), доктор филологических наук.

ORCID ID: 0000-0001-7955-7351

margaritavv@mail.ru

Исламова Юлия Валерьевна, доцент кафедры русского языка и литературы, Югорский государственный университет (628012, Российская Федерация, Ханты-Мансийский автономный округ - Югра, г. Ханты-Мансийск, ул. Чехова, д. 16), кандидат филологических наук.

ORCID ID: 0000-0003-3752-8418

islyv@yandex.ru

Бакшеева Марина Геннадьевна, доцент кафедры русского языка и литературы, Югорский государственный университет (628012, Российская Федерация, Ханты-Мансийский автономный округ - Югра, г. Ханты-Мансийск, ул. Чехова, д. 16), кандидат филологических наук.

ORCID ID: 0000-0002-3248-165X

baksheeva.marina@yandex.ru 